Vol. 44, N. 4 : pp. 425 - 431, December, 2001

ISSN 1516-8913 Printed in Brazil

AN INTERNATIONAL JOURNAL

\title{
Hydration Properties of Soybean Protein Isolates
}

\author{
Gabriel Remondetto ${ }^{\mathbf{1}}$; Maria Cristina Añon ${ }^{2}$ and Rolando Jose González ${ }^{\mathbf{1}^{*}}$ \\ ${ }^{1}$ Instituto de Tecnología de Alimentos. F.I.Q-U.N.L Paraje El Pozo - Ciudad Universitaria - CC 266 - 3000- Santa \\ $\mathrm{Fe}$, Argentina; ${ }^{2}$ Centro de Investigación y Desarrollo en Criotecnología de Alimentos - CONICET - UNLP. 47 y116 \\ -1900- La Plata, Argentina
}

\begin{abstract}
Hydration properties of soybean isolates with different processing conditions (heat treatments, $p H$ and protein concentrations) were studied. Degree of denaturation, solubility in water, in $0.2 \mathrm{~mol} / \mathrm{L} \mathrm{NaCl}$, and in media of different sodium dodecyl sulfate concentrations, viscosity and water imbibing capacity of the different samples were determinated and correlated. Treatments at temperatures higher than $80^{\circ} \mathrm{C}$ denatured $11 \mathrm{~S}$ and $7 \mathrm{~S}$ proteins, leading to exposure of hydrophobic groups, which produced insoluble aggregates either in water or in high ionic strength media. These isolates possessed high water imbibing capacities and gave rise to viscous dispersions. Significant correlations were obtained between hydration properties and the " $m$ " coefficient as calculated by a power law equation relating viscosity with the protein concentration of the dispersion. This " $m$ " coefficient also correlated with the denaturation enthalpy of the protein isolates. On the basis of these results, it might be suggested that the " $m$ " coefficient - dependent of the hydrodynamic behaviour of the particles - was a good estimator of the degree of protein denaturation.
\end{abstract}

Key words: Soybean proteins, hydration properties, protein isolates functional properties

\section{INTRODUCTION}

Soy isolates are the most highly refined soybean proteins commercially available.Effects of proccesing conditions on the functional properties of protein isolates have been studied by many authors (Pour El, 1981; Remondetto, 1997; Kinsella, 1979; Shiga \& Nakamura, 1987; Arce et al., 1989). Nevertheless, studies regarding pilot plant scale are scarce (Delgado et al., 1989; González et al., 1995), except for those registered as patents (Calvert, 1995; Potito De Paolis, 1972; Potito De Paolis, 1973). This type of investigation becomes important to obtain information about the necessary processing conditions required for the industrial manufacture of protein isolates with given charasteristics. Most of the studies relating functional properties to structural and physicochemical properties analyze isolates prepared in a laboratory scale and modified by thermal, chemical or enzymatic treatment after its preparation (Kinsella, 1979; Urbansky et al., 1983; Fiora et al., 1990; Sorgentini et al., 1991; Sorgentini et al., 1995; Petruccelli \& Añón, 1994 (I); Petruccelli \& Añón, 1994 (II) ).

The objetive of our study was to evaluate the hydration properties of soybean protein isolates obtained in a pilot plant and to correlate them with the extent of denaturation undergone by the different protein components ocuring in the samples.

* Author for correspondence 


\section{MATERIALS AND METHODS}

Raw Material: Deffated soybean flakes were supplied by Guipeba S.A., Santa Fe, Argentina. Composition of flakes, in $\mathrm{g} / 100 \mathrm{~g}$, were as follows: 45.0 protein ( $\mathrm{N}$ x 6.25), 13.0 moisture, 1.5 oil, 5.8 ash, protein dispersability index (PDI) was $78 \%$ (AACC, 1969)

Preparation of soybean protein isolates: A modification of the procedure described by Circle and Smith (1972) was used for preparing protein isolates (Fig.1).

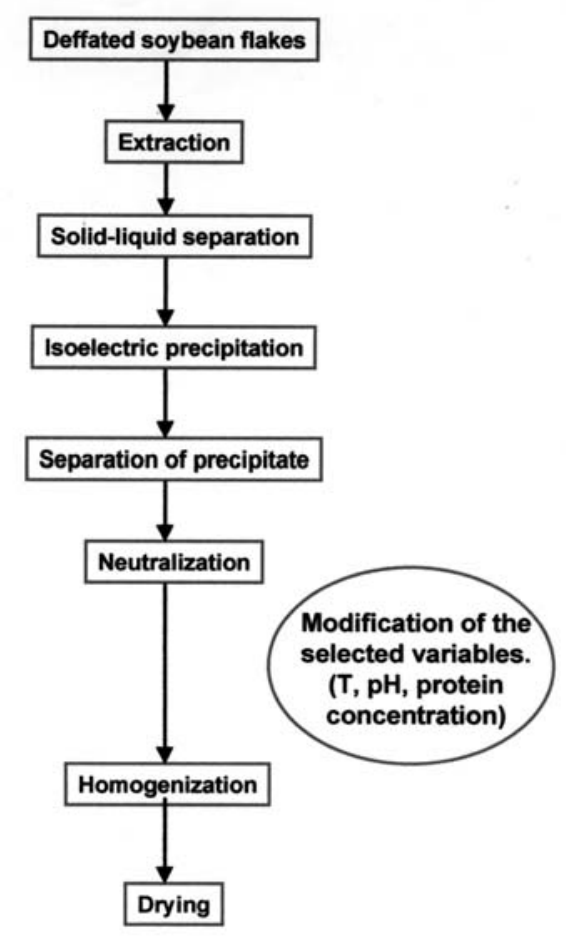

Figure 1 - Diagram of the experimental procedure used in the preparation of soybean protein isolates in the pilot plant.

Extraction was performed in water at $\mathrm{pH} 9$ and at $50^{\circ} \mathrm{C}$ with a solid/liquid ratio $1 / 10$, using anchor type stirrer $(60 \mathrm{rpm})$ for $1 \mathrm{~h}$. Solid- liquid separation was performed in a basket type centrifuge with filtering material. Isoelectric precipitation of the extract was carried out at $\mathrm{pH}$ 4.5 by adding $\mathrm{HCl}, 3 \mathrm{~mol} / \mathrm{L}$. Separation of the precipitate was carried out in a SAADH 205 model Westfalia centrifuge (Westfalia, Oelde, Germany). This procedure was used in all samples, variations of the solid concentrations, $\mathrm{pH}$ and temperature were done during neutralization.
Modifications of these variables were done using an agitation tank with an anchor type stirrer (90 rpm) and heating jacket.

An experimental design consisting of 3 variables at 3 levels (Box \& Behnken, 1960) was used. Fourteen treatments including twelve combinations of the three variables with a central point were obtained. Duplicate determinations were performed throughout (Table 1). The three levels of solid concentration used $(7.0-9.0$ and 11.0 , in $\mathrm{g} / 100 \mathrm{~g}$ ) were obtained by dilution of the washed precipitate.

Table 1 - Treatment conditions used.

\begin{tabular}{lccc}
\hline Sample & $\begin{array}{c}(\%) \text { Solids } \\
\text { concentration }\end{array}$ & $\begin{array}{c}\text { Temperature } \\
\left({ }^{\circ} \mathbf{C}\right)\end{array}$ & $\mathbf{p H}$ \\
\hline 1 & 11 & 65 & 10 \\
2 & 7 & 65 & 10 \\
3 & 9 & 65 & 11.5 \\
4 & 9 & 65 & 8.5 \\
5 & 11 & 80 & 11.5 \\
6 & 11 & 80 & 8.5 \\
7 & 7 & 80 & 11.5 \\
8 & 7 & 80 & 8.5 \\
9 & 9 & 80 & 10 \\
10 & 9 & 80 & 10 \\
11 & 11 & 95 & 10 \\
12 & 7 & 95 & 10 \\
13 & 9 & 95 & 11.5 \\
14 & 9 & 95 & 8.5 \\
\hline
\end{tabular}

Alkaline treatment performed to reach each $\mathrm{pH}$ level $(8.5,10$ and 11.5) was carried out at room temperature by adding $\mathrm{NaOH}, 3 \mathrm{~mol} / \mathrm{L} ; \mathrm{pH}$ was maintained for $10 \mathrm{~min}$, and then the sample was neutralized immediately.

Three types of thermal tratment were used $(65,80$ and $95^{\circ} \mathrm{C}$ ), by heating the dispersion with circulating hot water through the heating jacket, at a temperature $4{ }^{\circ} \mathrm{C}$ higher than that planned, each temperature level was maintained for $15 \mathrm{~min}$.

After thermal treatment, all samples were cooled to room temperature and homogenized before spray drying. A Manton Gaulin two-stage homogeneizer was used; pressures in the first and second stage were $2 \times 10^{5}$ and $5 \times 10^{5} \mathrm{~Pa}$, respectively. Drying was perfomed in a Niro Atomizer dryer (Niro-Atomizer, Copenhague, Denmark), with inlet an outlet temperature of 130 and $90^{\circ} \mathrm{C}$, respectively.

Determination of viscosity: Dispersions within the 
range 4.5-8.0 (g of protein $/ 100 \mathrm{~g}$ ) of the different protein isolate samples obtained by stirring at 90 rpm for $1 \mathrm{~h}$ at room temperature were prepared; the dispersions were allowed to stand for $2 \mathrm{~h}$ before each measurements. Rheograms were obtained at $30^{\circ} \mathrm{C}$ with a Haake Rotovisco RV2 viscosimeter (Haake, Karlsruhe, Germany) with a 50-500 rotor and NV system. Rotor velocity was between 0 and $50 \mathrm{rpm}$ (shear rate range from 0 to $270 \mathrm{~s}^{-1}$ ) using an acceleration rate of 25 $\mathrm{rpm} / \mathrm{min}$.

Velocity was maintained until a constant reading was obtained and then decreased to $0 \mathrm{rpm}$ at the same rate of the ascending part. Viscosity was calculated from the lower curve. The exponent " $\mathrm{m}$ ", corresponding to non-linear relationship between the viscosity expressed in centipoise (at $270 \mathrm{~s}^{-1}$ ), and the protein concentration expressed in $\mathrm{g} / 100 \mathrm{~g}$ protein, were estimated by regression:

$$
\eta_{\mathrm{app}}=\mathrm{A} \mathrm{C}^{\mathrm{m}} \quad[1]
$$

Where $\mathrm{A}$ and $\mathrm{m}$ are characteristic constants, $\mathrm{C}$ is the protein concentration of the dispersion.

Solubility: Solubility of the different samples obtained was determined in distilled water, $\mathrm{NaCl}$, $0.2 \mathrm{~mol} / \mathrm{L}$ and in two different SDS concentration (0.1 and $0.236, \mathrm{~g} / \mathrm{L})$. Dispersions containing 0.2 $\mathrm{g} / \mathrm{L}$ of protein in each solvent at $\mathrm{pH} 7.0$ were prepared; these were stirred with magnetic stirrer for $1 \mathrm{~h}$ at room temperature, centrifuged at $2000 \mathrm{x}$ $\mathrm{g}$ for $30 \mathrm{~min}$ at room temperature and the content of soluble nitrogen in the supernatant was determined by the Kjeldahl method. Results were expressed as (g.soluble N/g total N)x 100.

Water-Imbibing Capacity (WIC): It was determined by means of the device described by Baumann and modified by Torgenson and Toledo (Torgenson \& Toledo, 1997). Determinations were carried out at room temperature and the maximum (or the equilibrium value) was obtained; results were expressed as $\mathrm{ml}$ water/g isolate.

Differential Scanning Calorimetry,(DSC): The extent of denaturation of the different protein isolates was evaluated by DSC. A 910 Du Pont calorimeter (Du Pont, Wilmington, DE) with 7046 B Hewlett Packard recorder (Hewlett-Packard, Palo Alto, CA). Twenty percent dispersions (w/v) in distilled water of the different isolates obtained were analyzed. Fifteen to $20 \mathrm{mg}$ samples were placed in air-tight aluminum capsules. An empty capsule was used as reference, rate of heating was $10^{\circ} \mathrm{C} / \mathrm{min}$. Capsules were punctured at the end of scanning and the dry matter content was determined by heating at $105{ }^{\circ} \mathrm{C}$ until a constant weight was reached. Calibration of temperature and cell constant were determined using Indium as a standard (ASTM, 1979; ASTM, 1980). The area under the curve of each thermogram was measued by means of Morphomat 34 Zeiss image analyzer (Zeiss, Wetzlar, Germany); this value was used to calculate denaturation enthalpy.

Table 2 - Properties of the soybean protein isolates obtained in a pilot plant

\begin{tabular}{cccccccc} 
Sample & $\begin{array}{c}\Delta \mathbf{H} \\
(\mathbf{J} / \mathbf{g})\end{array}$ & $\begin{array}{c}\mathbf{W I C} \\
(\mathbf{m L} / \mathbf{g})\end{array}$ & $\begin{array}{c}\mathbf{S o l . H}_{\mathbf{2}} \mathbf{O} \\
\mathbf{( \% )}\end{array}$ & $\begin{array}{c}\text { Sol.NaCl } \\
(\mathbf{\%})\end{array}$ & $\begin{array}{c}\text { Sol.SDS } \\
(\mathbf{\%})\end{array}$ & $\begin{array}{c}\eta_{\text {app }} \\
(\mathbf{c P})\end{array}$ & $\mathbf{M}$ \\
1 & 7.10 & 5.0 & 56.0 & 44.0 & 96 & 37 & 2.57 \\
2 & 10.84 & 3.8 & 86.5 & 60.0 & 96 & 25 & 2.29 \\
3 & 8.36 & 4.4 & 54.0 & 41.5 & 92 & 37 & 2.64 \\
4 & 8.86 & 3.5 & 83.0 & 53.0 & 96 & 35 & 2.13 \\
5 & 3.99 & 6.7 & 15.0 & 13.0 & 82 & 23 & 4.01 \\
6 & 4.24 & 7.6 & 31.5 & 25.0 & 86 & 124 & 3.10 \\
7 & 1.72 & 7.8 & 22.0 & 19.5 & 83 & 112 & 3.56 \\
8 & 6.81 & 5.2 & 41.0 & 32.0 & 96 & 94 & 2.53 \\
9 & 7.60 & 5.5 & 60.0 & 49.0 & 93 & 32 & 2.54 \\
10 & 4.11 & 5.7 & 35.0 & 30.0 & 94 & 41 & 3.32 \\
11 & 1.88 & 6.3 & 15.5 & 15.0 & 72 & 25 & 3.68 \\
12 & -- & 10.1 & 19.0 & 13.0 & 66 & 197 & 3.69 \\
13 & -- & 8.1 & 15.6 & 12.5 & 68 & 77 & 4.05 \\
14 & -- & 6.3 & 20.6 & 17.0 & 69 & 87 & 3.77 \\
\hline
\end{tabular}

$\Delta \mathrm{H}$ : Denaturation entalphy; WIC: Water - Imbibing; Sol. $\mathrm{H}_{2} \mathrm{O}$ : Solubility in water;

Sol. NaCl: $0.2 \mathrm{~mol} / \mathrm{L}$; Sol. SDS: solubiity in Sodium Dodecyl Sulphate, $0.1 \mathrm{~g} / \mathrm{L}$;

$\eta_{\text {app }}$ : apparent viscosity of a $8 \%$ protein dispersion ; m: Coefficient. 


\section{RESULTS AND DISCUSSION}

The model describing the relationships between each property and process variables were discussed elsewhere (Remondetto,1997; González et al., 1995).

Table 2 shows the experimental results of all evaluations corresponding to the soybean protein isolates obtained. Samples were grouped according to the treatment temperature. DSC analysis is shown in Fig 2 .

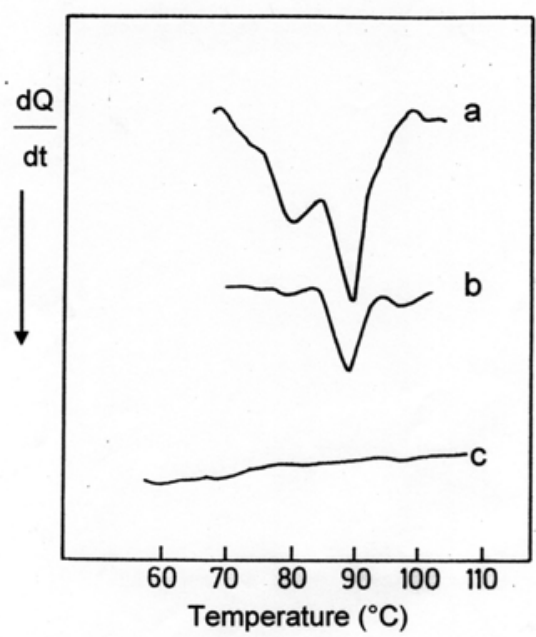

Figure 2 - Typical DSC thermograms of soybean protein isolates treated at $65^{\circ} \mathrm{C}(\mathrm{a}) ; 80^{\circ} \mathrm{C}(\mathrm{b})$ and $95^{\circ} \mathrm{C}(\mathrm{c})$

Thermograms of samples treated at $65^{\circ} \mathrm{C}$ showed the two endotherms corresponding to $7 \mathrm{~S}$ and $11 \mathrm{~S}$ fractions. Calculated values of enthalpy $\left(\Delta \mathrm{H}_{\mathrm{T}}\right.$ : $10.84-7.10 \mathrm{~J} / \mathrm{g}$ ) were lower than those corresponding to native isolates $\left(\Delta \mathrm{H}_{\mathrm{T}}\right.$ : $15-20$ J/g), (Petruccelli \& Añón, 1995), indicating partial denaturation of the proteins. The extent of denaturation reached was maximum at the highest $\mathrm{pH}$ at which the thermal treatment was performed, in agreement with previous results obteined at the laboratory scale (Petruccelli \& Añón, 1994 (I); Petruccelli \& Añón, 1995). Samples treated at $80^{\circ} \mathrm{C}$ contained almost totally denatured $\beta$ conglicinin and partially denatured glycinin $\left(\Delta \mathrm{H}_{\mathrm{T}}\right.$ : $7.6-1.2 \mathrm{~J} / \mathrm{g}$ ); while samples heated at $95^{\circ} \mathrm{C}$ were completely denatured, with the exception of sample 11 . This was probably due to a protective effect of the higher solids concentration level (11 $\%)$.

Solubility in the different solvents used led to show up the possible types of particle-particle and particle-solvent interaction predominating in dispersion behaviour (2). Solubility in $0.2 \mathrm{~mL} / \mathrm{L}$ $\mathrm{NaCl}$ showed a high linear correlation with solubility in water $(r=0.98)$ (Fig 3). An increase of ionic strength lowers solubility; thus decrease becomes larger as the extent of protein denaturation decreases (Table 2). This behaviour was in accordance with that described by Wagner and Añón (1990) with regard to commercially available soybean protein isolates. It is likely that the less denatured proteins expose a larger number of charged hydrophilic groups upon which $\mathrm{NaCl}$ would provide a protective effect, thus making possible closer proximity of molecules and therefore a higher extent of aggregation

Presence of $0.1 \mathrm{~g} / 1$ SDS markedly increased the solubilities of all samples. Values varied between 96 and 66. As expected, samples treated at $95^{\circ} \mathrm{C}$, exhibited the lowest solubility values (66-72) (Table 2). These results suggested that insolubility caused by the treatments was due to formation of aggregates largely estabilized by hydrophobic bonds. It has shown that both the thermal treatment and alkaline $\mathrm{pH}$ favor exchange $\mathrm{SH} / \mathrm{SS}$ reactions (Petruccelli \& Añón, 1995). Solubilities lower than $100 \mathrm{~g} / 100 \mathrm{~g}$ would then be expected in a medium containing SDS (in the absence of a reducing agent), mainly in the case of isolates treated at $95^{\circ} \mathrm{C}$.

It should be pointed out that soybean protein isolates, at the laboratory level which had undergone thermal tretments, had SDS-soluble aggregates. These aggregates were sensitive to the action of $\beta$-mercaptoethanol and were formed by

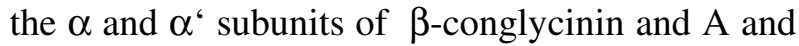
B glycinin polypeptides (Petruccelli \& Añón, 1994 (I)). Morover, the $\mathrm{pH}$ range used (8.5 to 11.5) favors dissociation of the AB-11AS subunit, thus facilitating the formation of $\beta-7 \mathrm{~S} / \mathrm{B}-11 \mathrm{~S}$ aggregate), (Petruccelli\& Añón,1995).

Isolates containing a higher content of denatured proteins and with lower solubility exhibited a higher capacity for water absorption (Table 2). Eight percent dispersions of these samples with the exception of samples 5 and 11 also showed viscosity values higher than those corresponding to isolates which underwent less severe thermal treatments. Sample 11, treated at $95^{\circ} \mathrm{C}$ contained a certain amount of native glicinin $\left(\Delta \mathrm{H}_{\mathrm{T}}: 1.88 \mathrm{~J} / \mathrm{g}-\right.$ Table 2) and a vey slight solubility in water. The presence of undenatured $11 \mathrm{~S}$ protein in the insoluble fraction would appear as a decrease of WIC (Sorgentini et al., 1991). On the other hand, 
conditions employed to obtain this isolate sample (high solids concentration, high $\mathrm{pH}$ and high temperature) could lead to the formation of more compact aggregates, producing lower viscosity. The same considerations may be extended to sample 5. These results are in agreement with those previously reported for both commercial soybean protein isolates and isolates at the laboratory scale (Sorgentini et al., 1991; Petruccelli \& Añón, 1994 (I); Petruccelli \& Añón, 1994 (II); Wagner \& Añón, 1990).

González et al. (1995) had previously shown that the viscosity, measured at a $270 \mathrm{~s}^{-1}$ velocity gradient of dispersions of different protein concentrations of soybean isolates could be expressed as: $\eta_{\text {app }}=A \cdot C^{\mathrm{m}}$, " $\mathrm{m}$ " being linearly correlated with the temperature of the thermal treatment. This type of relationship has been applied to many food systems containing hydrated particles (Holdsworth, 1971).

Wagner et al. (1992) reported that the viscosity of soybean protein isolates dispersion could be expressed by the power law and that furthermore, it may be expressed by an equation of the type

$$
\eta_{\text {app }}=\eta_{0}+\mathrm{a}[\mathrm{P}]^{\mathrm{n}}
$$

where $\eta_{\text {app }}$ is the initial viscosity, $[\mathrm{P}]$ is the concentration of the protein dispersion and a and $n$ are constants whose values depend on the nature of the polymer, the solvent and the temperature. This relationship allowed them to make evident the transition from a quasi-newtonian behaviour to a pseudoplastic one whenever the protein concentration increased. This transition was evident by the abrupt slope change. The change occurred at a protein concentration of approximately 3-4\%.

Analysis of the possible relationships existing between the evaluated properties of the isolates indicates good linear correlation for some of them and power law type correlation for others (Figures $3,4,5$, and 6 ).

Figure 4 shows negative correlation between WIC and $\mathrm{Sol} \mathrm{H}_{2} \mathrm{O}(\mathrm{r}=-0.84)$ and a significant increase was observed of WIC when $\mathrm{Sol} \mathrm{H}_{2} \mathrm{O}$ decreased below 40. As it was mentioned before the WIC was directly related to the degree of desnaturation, so solubility was a good indicator of degree of desnaturation.

Similarly there was a good negative correlation between the solubility in water and coefficient " $\mathrm{m}$ " $(\mathrm{r}=0.97)$ (Fig 5).

Taking into account that solubility decreases with increasing temperature of the thermal treatment therefore with an increase of the degree of denaturation undergone during treatment- it may be concluded that, for the group of samples analyzed, there existed a good correlation between "m" and $\Delta \mathrm{H}$ as measured by DSC ( $\mathrm{r}=-0.914)$ (Fig $6)$. It could be also noticed that all isolates that underwent mild thermal treatments - in addition to higher $\Delta \mathrm{H}$ values - showed " $\mathrm{m}$ " values below 3 . The value of this coefficient " $m$ ", associated to the hydronamic behaviour of the system, might be a good parameter to estimate the degree of protein desnaturation, as well as of the degree of particleparticle interaction. It should be emphasized that, although the system studied consisted of macromecules having complex quaternary structures, a behaviour parallel to those of models of macromolecules in solution could be thought (Rha \& Pradipasena, 1986).

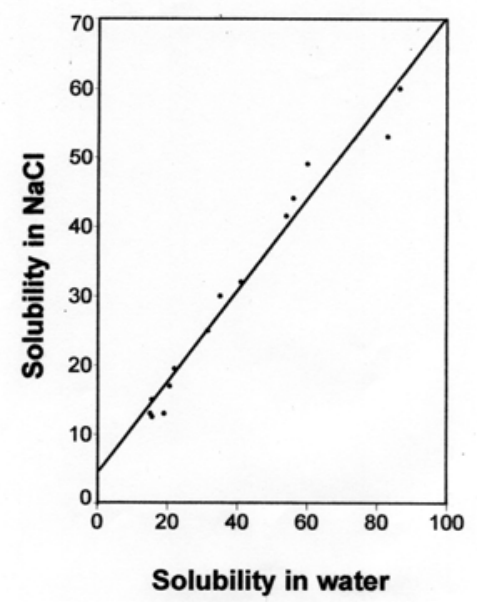

Figure 3 - Relationship between solubility in $\mathrm{NaCl} 0.2$ $\mathrm{mL} / \mathrm{L}$ and solubility in water of the soybean protein isolates under study.

\section{CONCLUSION}

The hydration properties of soybean isolates obtained at pilot plant scale and different processing variables showed good correlation between one another and also with the degree of denaturation. For these types of treatments, the water solubility and WIC were good estimators of the protein denaturation degree. The " $m$ " coefficient was an empirical measurement of the particle-particle interactions and it had also a high correlation with denaturation degree.This 
coefficient could be considered as a good indicator of the hydrodinamic volume of the particles or aggregates.

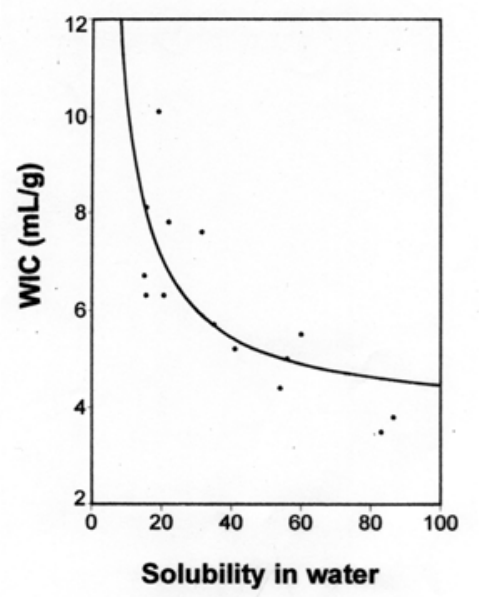

Figure 4 - Relationship between water imbibing capacity and solubility in water of the soybean protein isolates under study.

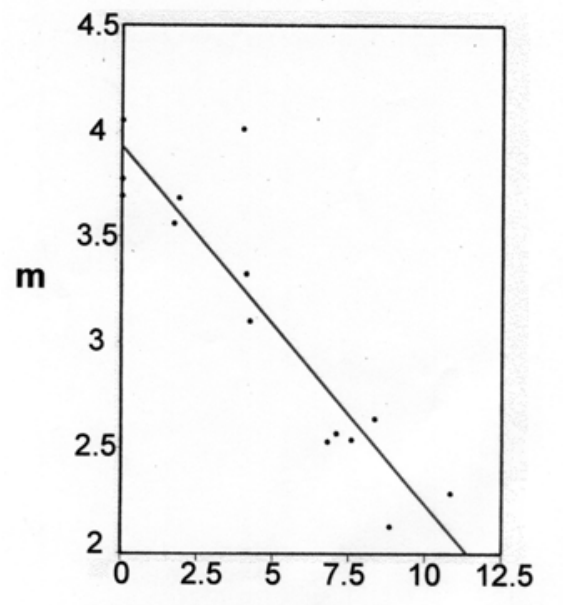

Entalphy of denaturation, $\Delta \mathbf{H}(\mathrm{J} / \mathrm{g})$

Figure 5 - Relationship between " $m$ " coefficient and solubility in water of the soybean protein isolates studied.

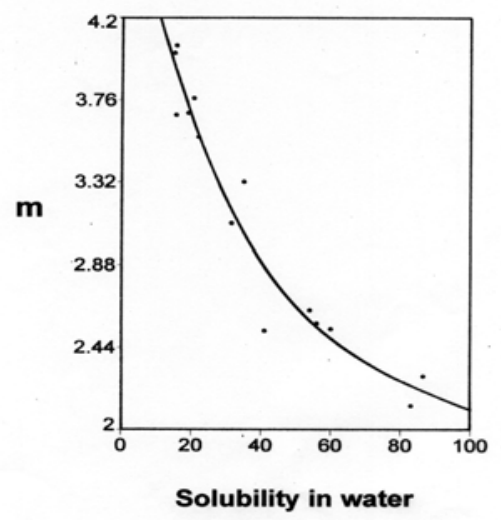

Figure 6 - Relationship between "m" coefficient and entalphy of denaturation of the soybean protein isolates under study.

\section{ACKNOWLEDGEMENTS}

Acknowledgements are made to Adriana Bonaldo and Liliana Santiago for their cooperation in laboratory works and to Univ.Nacional del Litoral for the finantial support of this research.

\section{RESUMO}

Estudaram-se as propriedades de hidratação de isolados de soja com diferentes condições de procesamento (tratamentos térmicos, $\mathrm{pH}$ e concentração de proteínas). Para diferentes amostras determinaram-se e correlacionaram-se o gráu de desnaturalização, a solubilidade em água, em $0,2 \mathrm{~mol} / \mathrm{L} \mathrm{NaCl}$ e em diferentes concentrações de dodecil sulfato de sódio, viscosidade e capacidade de absorção de água. Os tratamentos a temperaturas superiores aos $80^{\circ} \mathrm{C}$ desnaturaram as fracções $11 \mathrm{~S}$ e $7 \mathrm{~S}$, provocando a exposição de grupos hidrofóbicos os que produziram agregados insolúveis, em água como em solução com alta força iónica. Estes isolados posuiam alta capacidade de absorção de água e dispersões com alta viscosidade. Achou-se uma correlação significativa entre as propriedades de hidratação e o coeficiente "m", calculado através da função de potência que relaciona a viscosidade com a concentração proteica da dispersão. Este coeficiente "m" também correlacionou com a entalpia dos isolados. Sobre a base destes resultados poderia-se sugerir que o coeficiente "m" - dependente do comportamento hidrodinâmico das partículas - foi um bom estimador do grau de desnaturação proteica. 


\section{REFERENCES}

AACC (1969), Approved methods of the American Association of Cereal Chemists, ed. Schaefer Chairman. W. C.. Published by American Association of Cereal Chemists. USA.

Arce, C. B.; Pilosof, A. M. R. and Bartholomai, G. B. (1989), Modificación de las propiedades funcionales de concentrados de proteina de soja. Paper presented at IV Conferencia Mundial de Investigación en Soja. Buenos Aires, Argentina.

ASTM Standards, American Society for Testing and Materials, Philadelphia, Norms E 698/79 and 474/80.

Box, G. E. P. and Behnken, D. W. (1960), Some new three designs for the study of quantitative variables. Technometric, 2, 455-475.

Calvert, F. E. (1972). Canadian patent 907398.

Circle, S. J. and Smith, A. K. (1972), Processing soy flours, protein concentrates and protein isolates. In: Soybean: Chemistry and Technology,. AVI Publishing Company, Inc., USA, pp. 274.

Delgado De Layño, M.; López De Ogara, M. C.; Moya, S. A.; Segal, M. B. and Macchi, R. A. (1989), Obtención de aislados de soja. Influencia del tratamiento térmico, luego de la neutralización, sobre la funcionalidad de los mismos. Paper presented at IV Conferencia Mundial de Investigaciones de Soja. Buenos Aires. Argentina.

Fiora, F. A.; Pilosof, A. M. R. and Bartholomai, G. B. (1990), Physicochemical properties of soybean protein related to flow, viscoelastic, mechanical and water-holding characteristics of gels. Journal of Food Science, 55, 133-136.

González, R.; Remondetto, G.; Santiago, L.; Coutz, R. and Bonaldo, A. (1995), Efectos de variables del proceso en planta piloto sobre algunas propiedades de aislados proteicos de soja. Revista Española de Ciencia y Tecnología de Alimentos, 35(1), 77-91.

Holdsworth, S. D. (1971), Aplicability or rheological models to the interpretation of flow and processing behaviour of fluid food products. Journal Texture Studies, 2, 393-418.

Kinsella, J. E. (1979), Functional properties of soy proteins. Journal American Oil Chemistry Society, 56, 242-258.

Petruccelli, S. and Añón, M. C. (1994), The realtionship between the method of preparation and the structural and functional properties of soy protein isolates. Part I: Structural and hydration properties. Journal Agriculture Food Chemistry, 42, 2161-2169.

Petruccelli, S. and Añón, M. C. (1994), The relationship between the method of preparation and the structural and functional properties of soy protein isolates. Part II: Surface properties. Journal Agriculture Food Chemistry, 42, 2170-2176.

PetruccelliI, S. and Añón, M. C. (1995), Soy protein isolate components and their interaction. Journal Agriculture Food Chemistry, 43, 1762-1767.

Petruccelli, S. and Añón, M. C. (1995), Thermal aggregation of soy protein isolate. Journal Agriculture Food Chemistry, 43, 3035-3042.

Potito De Paolis, U. S. (1972), Patent 3,682,646.

Potito De Paolis, U. S. (1973), Patent 3,716,372.

Pour El, A. (1981), Functionality and protein structure. In: Protein Functionality in Foods, ed. Cherry, J.P. ACS Symposium Series. 147, pp. 1-20.

Remondetto, G. E. (1997), Estudio de propiedades de aislados proteicos de soja obtenidos en planta piloto y su relación con características estructurales. Trabajo de Tesis Master en Ciencia de Alimentos. Facultad de Ingeniería Química, Universidad Nacional del Litoral.

Rha, C. K. and Pradipasena, P. C. (1986), Viscosity of protein. In: Functional Properties of Food Macromolecules, ed. Mitchell, J. R. and Ledward, D. A. Elsevier Applied Science. London, Chapter 2, pp. $79-120$.

Shiga, K. and Nakamura, Y. (1987), Relation between denaturation and some functional properties of soybean protein. Journal Food Science. 52, 681-684.

Sorgentini, D. A. ; Wagner, J. R. and Añón, M. C. (1995), Effects of thermal treatment of soy protein isolate on the characteristics and structure: function relationship of soluble and insoluble fractions. Journal Agriculture Food Chemistry, 43, 2471-2479.

Sorgentini, D. A.; Wagner, J. R.; Arrese, E. L. and Añón, M. C. (1991), Water imbibing capacity of soy protein isolates. Influence of protein denaturation. Journal Agriculture Food Chemistry, 39, 1386-1391.

Torgenson, H. and Toledo, R. T. (1997), Physical properties of protein preparations to their functional characteristics in comminuted meat systems. Journal of Food Science, 42, 1615-1620.

Urbansky, G. E.; Wel, L. S.; Nelson, A. I. and Steimberg, M. P. (1983), Flow characteristics of soybeans constituents controlled by ratio of total to imbibed water. Journal of Food Science, 48, 691-694.

Wagner, J. R. and Añón, M. C. (1990), Influence of denaturation, hydrophobicity and sulfhidryl content on solubility and water absorbing capacity of soy protein isolate. Journal of Food Shience, 50, 765-770.

Wagner, J. R.; Sorgentini, D. A. and Añón, M. C. (1992), Effect of physical and chemical factor on rheological behavior of commercial soy protein isolate: Protein content, water imbibing capacity, salt addition, and thermal treatment. Journal Agriculture Food Chemistry, 40, 1930-1934.

Received: September 22, 1999; Revised: September 28, 1999; Accepted: February 16, 2001. 